\title{
STUDI PENGOLAHAN SOSIS IKAN KERANDANG (Channa pleurophthalma) DENGAN BAHAN PENGISI KACANG MERAH (Phaseolus vulgaris L)
}

\author{
(Study Of Sausage Fish Processing Kerandang (Channa pleurophthalma) With Red Beans \\ (Phaseolus vulgaris L) Filler Material) \\ Restu \\ Fakultas Perikanan Universitas Kristen Palangkaraya \\ e-mail:restului@gmail.com
}

Article Submitted : 16-06-2019

Article Accepted : 02-10-2019

\begin{abstract}
This study diversified processing of fish. The aims of the experiment completely randomized design to study the effect of red bean paste in the processing of fish sausage kerandang (Channa pleurophthalma). Results showed that the addition of red bean paste on the flesh of the fish kerandang very significant effect. The Best fish sausage obtained $\mathrm{C}$ treatment, namely by mixing fish meat kerandang creamed 500 grams with 300 grams of red bean paste. Criteria nutritions value generated as follows: protein $=16.45 \%$; Carbohydrates $=24.32 \%$; Fat $=1.07 \%$; water $=58.53 \%$; the average value of organoleptic $=7.41$ on hedonic scale. Specifications sausage produced is clean and attractive, distinctive smell of sausage and appealing taste, peculiar taste of fish sausage and tasty, with a texture quite compact.
\end{abstract}

Keyword : fish sausage kerandang, red bean

\section{PENDAHULUAN}

Dalam upaya pemenuhan kebutuhan protein hewani dan pola konsumsi masyarakat terhadap ikan, perlu adanya diversifiksi produk olahan terhadap ikan dengan penerapan teknologi yang tepat, mudah dan murah, mudah untuk disajikan, mempunyai nilai gizi yang baik serta disukai oleh masyarakat.

Pengolahan hasil perikanan di Kalteng umumnya masih bersifat tradisional yaitu berupa ikan asin/kering; kerupuk; ikan asap, wadi dan pakasam (Anonim, 2001). Sedangkan hasil olahan yang lebih moderen dan yang sangat disukai seperti nuget ikan dan sosis ikan belum banyak dilakukan.

Sosis merupakan makan yang diolah dari daging ternak maupun ikan dengan cara menggiling daging hingga halus, diberi bumbu, bahan pengikat, dibungkus dengan casing bulat panjang (usus hewan, plastik bungkus es mambo, daun pisang), kemudian dimasak dengan cara dikukus, direbus maupun diasap hingga matang. Ikan dan kacang merah dapat digunakan sebagai bahan dasar pembuatan sosis karena mengandung protein hewani dan nabati yang cukup tinggi, dengan demikian dapat membantu pemenuhan protein bagi keluarga.

Jenis ikan yang sudah pernah diolah menjadi sosis seperti ikan tenggiri, tongkol, Lele dumbo, Patin, Nila, sedangkan jenis ikan lokal air tawar yang berukuran besar dan banyak dagingnya seperti ikan Karandang (Channa pleurophthalma) belum pernah dicoba dibuat sosis ikan. Sebab itu perlu dicoba membuat sosis dengan bahan dasar dari ikan lokal tersebut.

Ikan Kerandang adalah ikan yang hidup di diperairan umum daratan (sungai, danau, waduk) tersebar di pulau Sumatera dan Kalimantan. Di Kalimantan Tengah ikan 
kerandang dapat tumbuh dengan panjang mencapai $40 \mathrm{~cm}$ dan berat $2 \mathrm{~kg} /$ ekor, harganya \pm Rp.25.000,-/kg. Ikan kerandang hasil tangkapan nelayan biasanya berjumlah banyak terutama pada musim kemarau. Hasil tangkapan ini lebih banyak diolah menjadi ikan asin (Anonim, 2010). Sebab itu perlu dicoba alternatif lain untuk mengolah daging ikan ini.

Hasil uji laboratorium kadar proksimat daging segar ikan kerandang dari Kalimantan Tengah: kadar air 79,21\%; protein 19,5\%; lemak $0,22 \%$; abu 1,07\%; albumin 3,5\%; Zn 2,35\% (Firliani dkk, 2013). Daging ikan ini tidak mempunyai daya ikat seperti daging ikan balida, sehingga dalam buat sosis perlu bahan pengikat dan pengisi agar dapat membentuk ikatan yang kompak saat proses pemasakan.

Penambahan bahan pengikat dan bahan pengisi berfungsi untuk menarik air, memberi warna khas, membentuk tekstur yang padat, memperbaiki stabilitas emulsi, menurunkan penyusutan waktu pemasakan, memperbaiki cita rasa dan sifat irisan. Kacang merah (Phaseolus vulgaris L) kering mengadung Karbohidrat $61,2 \%$; protein $22,3 \%$; lemak $1,7 \%$; kalsium $0,26 \%$; fosfor $0,41 \%$; zat besi $0,06 \%$; Vit A 30 SI; B1 $0,005 \%$ dan vit B2 0,002\% (Direktorat Gizi,Depkes, 1992). Penambahan pasta kacang merah ke dalam produk olahan daging berfungsi sebagai binding, shaping, dan extender serta berperan untuk mengurangi biaya produksi dalam pengolahan produk olahan daging (Ranken, 2000).

Menurut Tjokroadikoesumo (1986), tepung tapioka mengandung amilopektin yang tinggi sehingga mempunyai daya mengikat yang bagus, tidak mudah menggumpal, tidak mudah pecah atau rusak, dan suhu gelatinisasinya relatif rendah. Aryani (2002), melaporkan bahwa suhu pengukusan $90^{\circ} \mathrm{C}$ selama 30 menit menghasilkan nugget ikan terbaik. Pemberian tepung tapioka $15 \%$ dari total daging ikan toman dengan suhu pengukusan $90^{\circ} \mathrm{C}$ selama 20 menit menghasilkan bakso terbaik dalam pengolahan bakso ikan toman (Restu, 2012); pemberian tapioka 5\% dari total berat ikan toman yang dikukus pada suhu $90^{\circ} \mathrm{C}$ selama 30 menit menghasilkan nuget terbaik (Restu, 2013).

Hasil penelitian ini diharapkan dapat diadopsi oleh masyarakat untuk penganekaragaman olahan hasil perikanan.

\section{METODE PENELITIAN}

\section{Bahan}

Bahan yang digunakan dalam penelitian ini adalah ikan karandang (Channa pleurophthalma) dengan berat rerata $0,7-1,2$ kg/ekor; kacang merah; tapioka dan bumbu (garam, marica, bawang putih, bawang merah), air es, serta bahan kimia untuk uji proksimat.

\section{Metode}

Penelitian ini dilakukan dengan metode percobaan, menggunakan Rancangan Acak Lengkap (Sastrosoepadi, 1999). Terdiri dari tiga perlakuan dan tiga ulangan, sebagai berikut:

Perlakuan :A= Daging ikan kerandang 500 gr + 100 gr Pasta Kacang merah

Perlakuan:B = Daging ikan kerandang 500 gr + 200 gr Pasta Kacang merah

Perlakuan: $\mathrm{C}=$ Daging ikan kerandang 500 gr + 300 gr Pasta Kacang merah

Selanjutnya dimasak dengan cara dikukus pada suhu $90^{\circ} \mathrm{C}$ selama 30 menit.

Pengamatan dilakukan setelah proses pembuatan sosis selesai, yaitu meliputi uji kimia terhadap kadar protein, karbohidrat, lemak, kadar air, dan uji orgnoleptik (uji tingkat kesukaan oleh para panelis) terhadap produk sosis kemudian dilakukan analisis data.

Tahapan penelitian adalah sebagai berikut:

1. Ikan karandang segar dengan berat 0,7 $1,2 \mathrm{~kg} \mathrm{~kg} /$ ekor, dimatikan, dibuang sisik, dicuci, dibelah membujur (fillet), diambil daging (tanpa kulit dan tulang).

2. Daging bersih, dipotong kecil, dicampur dengan air es kemudian diblender 
3. Daging lumat dicampur dengan bumbu, tapioka dan pasta kacang merah, diaduk hingga dianggap merata.

4. Dimasukkan kedalam casing es mambo berdiameter $3 \mathrm{~cm}$ dengan panjang $10 \mathrm{~cm}$.

5. Dikukus pada suhu $90 \pm 2^{\circ} \mathrm{C}$ selama 30 menit menggunakan Panci pengukus.

6. Didinginkan

7. Analisa kandungan proksimat
8. Digoreng untuk uji organoleptik

\section{HASIL DAN PEMBAHASAN}

Hasil analisis proksimat terhadap masing-masing adonan masing-masing perlakuan penambahan pasta kacang merah, seperti pada tabel 1 .

Tabel 1. Data Hasil Analisis kadar proksimat adonan sosis mentah.

\begin{tabular}{cccccc}
\hline No & Perlakuan & Kadar Air (\%) & Protein (\%) & Lemak (\%) & $\begin{array}{c}\text { Karbohidrat } \\
(\%)\end{array}$ \\
\hline 1. & A & 76,28 & $11,86 \mathrm{bc}$ & 0,62 & 11,24 \\
2 & B & 71,81 & $12,93 \mathrm{ab}$ & 0,94 & 14,32 \\
3 & C & 67,13 & $14,15 \mathrm{ac}$ & 1,25 & 17,47 \\
\hline
\end{tabular}

\section{Kadar Protein}

Hasil pengujian laboratorium terhadap kadar protein sosis ikan kerandang dengan bahan pengisi kacang merah setelah melalui proses pengukusan pada suhu $90 \pm 2^{\circ} \mathrm{C}$ selama 30 menit dan penyimpanan dalam lemari pendingin selama 1 hari memperlihatkan bahwa semakin banyak penambahan pasta kacang merah, maka semakin besar kadar protein yang dikandung sosis. Lihat Gambar 1.

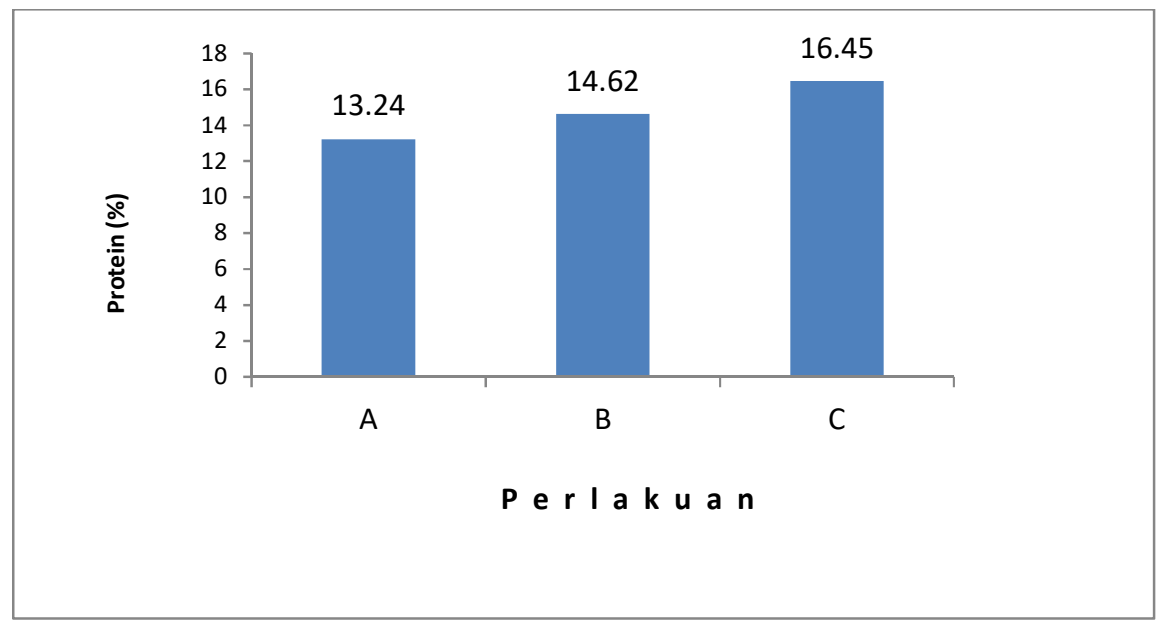

Gambar 1. Rerata Kadar Protein (\%) tiap Perlakuan

Kenaikan persentase kadar protein dari adonan setelah proses pengukusan padahu $90 \pm 2^{\circ} \mathrm{C}$ selama 30 menit dan pendinginan selama satu hari pada setiap perlakuan berkisar antara 4,8 s/d 7,1\%, hal ini diduga karena proses pengukusan mengakibatkan penarikan/keluarnya air dari dalam adonan. kadar protein rerata tertinggi yang dihasilkan 
dalam produk sosis ikan kerandang adalah pada perlakuan $\mathrm{C}=16,45 \%$, kemudian diikuti oleh perlakuan $\mathrm{B}=14,62 \%$ dan perlakuan $\mathrm{A}=13,24 \%$. Kadar protein semua perlakuan berada diatas standar mutu sosis sesuai (SNI 01-3820-1995), yaitu bahwa nilai kadar protein sosis minimal $10 \%$, sehingga kadar protein yang dihasilkan sosis dengan bahan dasar ikan kerandang dan pasta kacang merah memenuhi persyaratan mutu dan keamanan bahan pangan.

Hasil analisis keragaman (Anova) kadar protein sosis ikan karandang menunjukan bahwa perlakuan pemberian kadar kacang merah yang berbeda memberikan pengaruh yang sangat nyata terhadap kadar protein.

Kadar protein tertinggi yang dikandung oleh produk sosis ikan kerandang Perlakuan $\mathrm{C}=16,45 \%$ ini lebih tinggi jika dibandingkan kadar kadar protein sosis ikan ekor kuning (Caesio spp) menggunakan casing kolagen setelah penyimpanan 1 hari dalam lemari pendingin sebesar 15,61\% (Verly Dotulong, 2009), protein otak-otak lele dumbo yaitu 12,89\% (Restu, 2003) maupun bakso ikan toman 12,49\% (Restu, 2011).

Hal ini berarti bahwa penambahan pasta kacang merah dalam pengolahan sosis ikan berpengaruh sangat nyata, yaitu semakin besar persentase pasta kacang merah maka semakin besar pula kadar protein dalam produk sosis ikan kerandang. Menurut Direktorat Gizi (1992) Kacang merah mengandung protein sebesar $22,3 \%$ dari berat kering. Sebab itu kacang merah dapat menambah nilai gizi, Kacang merah kering merupakan sumber protein nabati, karbohidrat kompleks, serat, vitamin B, folasin, tiamin, kalsium, fosfor, dan zat besi.

Kadar protein sosis ikan kerandang ini berada diatas standar minimum hasil olahan dari ikan, yaitu sebesar 9\% (DSN, 1991).

\section{Kadar Karbohidrat}

Hasil pengujian laboratorium terhadap kadar karbohidrat (\%) sosis ikan kerandang menujukan bahwa semakin banyak penambahan pasta kacang merah maka semakin tinggi kadar karbohidrat yang dikandung produk. Lihat Gambar 2.

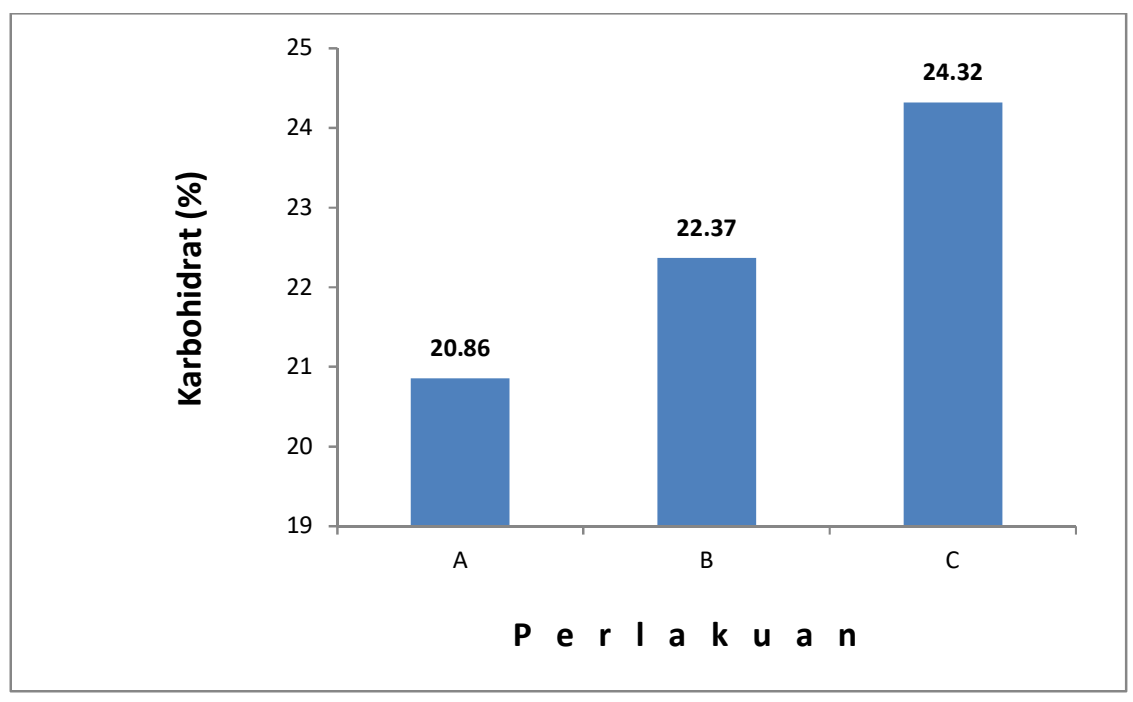

Gambar 2. Rerata kadar Karbohidrat (\%) setiap perlakuan setelah proses pengukusan

Kenaikan persentase kadar karbohidrat dari adonan setelah proses pengukusan padahu $90 \pm 2^{\circ} \mathrm{C}$ selama 30 menit dan pendinginan selama satu hari pada setiap perlakuan berkisar antara $31 \% \mathrm{~s} / \mathrm{d} 46,12 \%$, hal ini diduga karena proses pengukusan mengakibatkan penarikan/keluarnya air dari dalam adonan, sehingga kadar 
karbohitdratnya meningkat. Rerata karbohidrat yang diperoleh pada produk sosis ikan kerandang perlakuan $\mathrm{C}=24,32 \%$, kemudian diikuti oleh perlakuan $\mathrm{B}=22,37 \%$ dan perlakuan $\mathrm{A}=20,86 \%$. Kandungan kadar karbohidrat semua perlakuan ini lebih rendah bila dibandingkan dengan kadar karbohidrat sosis ikan gabus (Channa striata) sebesar 47,65\% (Yulindra dkk, 2013) maupun sosis ikan kembung (Rastreliger sp.) sebesar 37,88\% (Iwenda, dkk, 2016). Namun lebih rendah dari rerata kadar karbohidrat bakso ikan toman yaitu 16,5 persen (Restu, 2011).

Hasil analisis keragaman menunjukan bahwa perlakuan penambahan pasta kacang merah pada sosis ikan kerandang menunjukan perbedaan yang sangat nyata terhadap kadar karbohidrat, dimana $\mathrm{F}$ hitung $>\mathrm{F}$ tab $1 \%$.
Hasil penelitian menunjukan bahwa kadar kabohidrat rerata tertinggi yang dihasilkan dalam produk sosis ikan toman adalah pada perlakuan $\mathrm{C}=24,32 \%$, kemudian diikuti oleh perlakuan $\mathrm{B}=22,37 \%$ dan perlakuan $\mathrm{A}=20,86 \%$. Berdasarkan hasil uji beda nyata terkecil (BNT), menunjukan bahwa diantara semua perlakuan berbeda nyata terhadap kadar karbohidrat yang dikandung oleh produk sosis ikan kerandang.

\section{Kadar Lemak}

Hasil analisis kadar lemak pada produk sosis ikan kerandang, menunjukan bahwa semakin tinggi persentase kacang merah maka semakin besar kadar lemak yang dikandung produk, Lihat gambar 3.

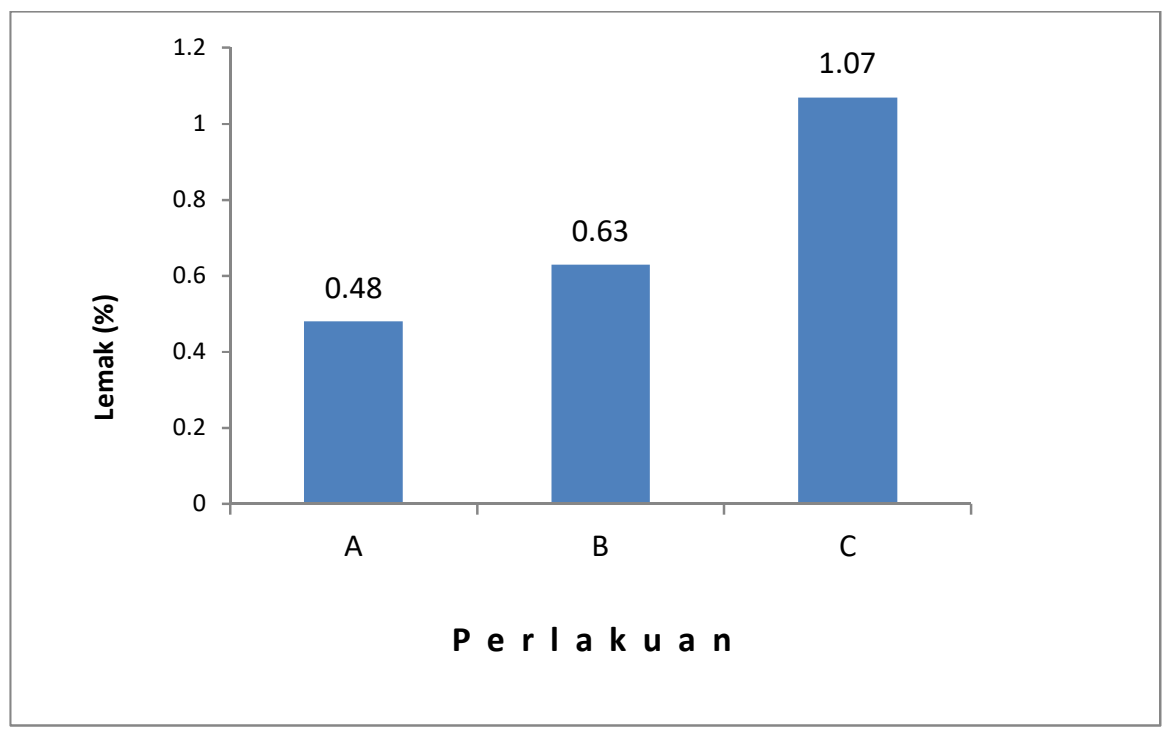

Gambar 3. Rerata Kadar Lemak (\%) sosis ikan kerandang setiap perlakuan

Kadar lemak rerata tertinggi di kandung oleh perlakuan $\mathrm{C}=1,07 \%$, kemudian diikuti oleh perlakuan $\mathrm{B}=0,63 \%$, dan $\mathrm{C}=0,48 \%$. Kadar lemak yang dikandung produk sosis ikan kerandang ini lebih rendah bila dibandingkan dengan kadar lemak sosis ikan lele dumbo $8,05 \%$ setelah dilakukan pengukusan selama 25 menit (Simon, dkk, 2003), kadar lemak sosis ikan ekor kuning 2,32\% (Verly Dotulong, 2009) dan kadar lemak sosis ikan tenggiri dan daun kelor (Nurlaila, et al, 2016), maupun kadar lemak otak-otak ikan lele dumbo yaitu 3,01\% (Restu, 2003). Hal ini disebabkan karena panas proses pengukusan yang mengakibatkan keluarnya lemak dari adonan sosis ikan kerandang. 
Hasil analisis keragaman menunjukan bahwa penambahan pasta kacang merah menunjukan perbedaan yang sangat nyata terhadap kadar lemak produk sosis ikan kerandang pada setiap perlakuan, yaitu: $\mathrm{F}$ hit $=396,74>\mathrm{F}$ tab $1 \%=10,92$.

\section{Kadar Air}

Hasil penelitian menunjukan bahwa kadar air rerata terendah terdapat pada produk sosis ikan kerandang perlakuan $\mathrm{C}=$ $58,53 \%$, Kadar air yang dikandung oleh produk sosis ikan kerandang ini lebih rendah jika dibandingkan kadar air otak-otak lele dumbo yaitu 59,56\% (Restu, 2003), maupun kadar air sosis ikan ekor kuning yaitu 63,64\% (Verly Dotulong, 2009). Hal ini diduga proses pengukusan selama 30 menit menyebabkan air keluar dari adonan sosis tersebut. Semakin besar kadarpasta kacang merah maka semakin rendah kadar air yang dikandung pruduk sosis ikan kerandang. Walaupun demikian kadar air tersebut tidak melampaui kadar air standar mutu maksimal yaitu $80 \%$ untuk produk sosis.

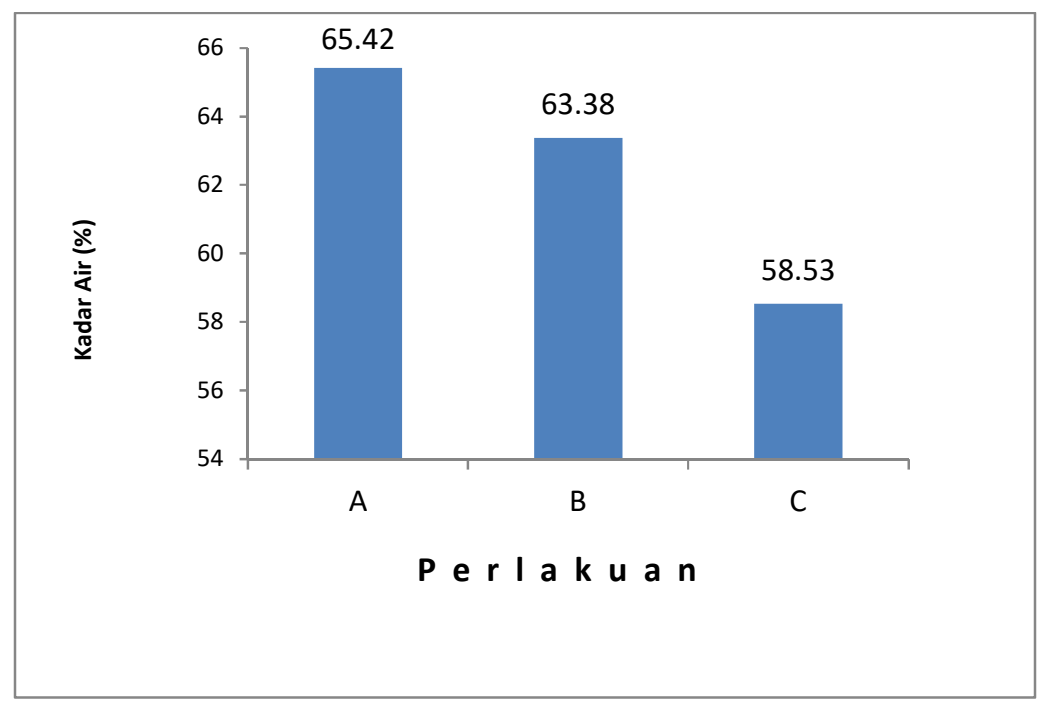

Gambar 4. Rerata Kadar Air (\%) sosis ikan kerandang setiap perlakuan

Hasil analisis keragaman menyatakan bahwa perlakuan persentase pasta kacang merah menunjukan perbedaan yang sangat nyata terhadap kadar air yang dikandung oleh produk, dimana $\mathrm{F}$ hitung $=18883,78>\mathrm{F}$ tab $1 \%=10,92$. Berdasarkan hasil uji beda nyata terkecil (BNT), menunjukan bahwa diantara semua perlakuan berbeda sangat nyata terhadap kadar air yang dikandung oleh produk sosis ikan kerandang.

\section{Uji Organoleptik}

Hasil uji organoleptik oleh lima orang panelis terlatih terhadap sosis ikan kerandang menunjukkan bahwa produk dengan nilai rerata tertinggi dihasilkan oleh perlakuan $\mathrm{C}=$ 7,6. Kriteria disukai oleh panelis, rasa gurih dan empuk, kemudian diikuti oleh perlakuan $\mathrm{B}=7,3$ dan perlakuan $\mathrm{A}=7,2$. Nilai uji organoleptik perlakuan $\mathrm{C}$ ini lebih tinggi jika dibandingkan dengan nilai uji organoleptik nuget ikan lele dumbo perlakuan terbaik yaitu 7,1 (Restu, 2003), maupun nilai rasa sosis lele dumbo yaitu 5,2 (Simon BW dkk, 2003). 
Tabel 5. Rerata Hasil Uji Organoleptik terhadap kenampakan, bau, rasa dan kekenyalan Produk sosis ikan kerandang

\begin{tabular}{cc}
\hline Perlakuan & Rata-rata \\
\hline A & 7,08 \\
B & 7,28 \\
C & 7,41 \\
\hline
\end{tabular}

Pada Tabel 5. diatas telihat bahwa perlakuan persentase pasta kacang merah sebesar 300 gram memberikan cita rasa terbaik dengan nilai 7,41 (skala hedonik). Spesifikasi: warna normal, tekstur cukup, rasa enak dan gurih, bau khas sosis ikan.

\section{KESIMPULAN DAN SARAN}

\section{Kesimpulan}

Pengolahan sosis Ikan kerandang (Channa pleurophthalma) terbaik dalam penelitian ini adalah perlakuan $\mathrm{C}$, yaitu dengan mencampur dagingikan kerandang lumat 500 gram dengan pasta kacang merah 300 gram. Kriteria nilai gizi yang dihasilkan sbb: protein $=16,45 \%$; Karbohidrat $=$ $24,32 \%$; Lemak $=1,07 \%$; air $=58,53 \%$; rerata nilai organoleptik $=7,41$ pada skala hedonik. Spesifikasi sosis yang dihasilkan (penampilan) bersih dan menarik, bau khas sosis dan menarik selera, rasa khas sosis ikan dan enak, dengan tesktur cukup kompak.

\section{Saran}

Apabila ingin membuat sosis ikan kerandang (Channa pleurohthalma), sebaiknya menggunakan pasta kacang merah sebanyak 300 gram dari total berat daging ikan bersih, sehingga diperoleh sosis ikan kerandang kualitas yang ideal.

\section{DAFTAR PUSTAKA}

Anonim, (2001). Laporan Hasil Uji Coba Pengolahan Hasil Perikanan pada LPPMHP. Dinas Kelautan Dan perikanan Propinsi Kalimantan Tengah, Palangkaraya.

, (2011). Kelautan Dan Perikanan Provinsi Kalimantan Tengah Dalam
Angka tahun 2010. Dinas Kelautan Dan Perikanan Provinsi Kalimantan Tengah.

Aryani, (2002). Karakteristik Binding Agent dengan Kombinasi Tapioka dan Tapioka Termodifikasi Serta Aplikasinya Dalam Produksi Nuggets Ikan Gabus (Ophiocephalus striatus). Unibraw. Malang.

Ayu Gelang P, (2016). Pengaruh

Penggunaan jenis dan Jumlah Bahan

Pengisi Terhadap Hasil Jadi Sosis Ikan Gabus (Channa striata). Jurnal Tata Boga Vol 5 no 1 (2016)

Direktorat Gizi, Depkes, (1992). Daftar Komposisi Bahan Makanan. Departemen Kesehatan RI

Fitriani, dkk (2013). Chemical Composition and Amino Acid Profile of Channidae Collected From Central Kalimantan, Indonesia. IEESE Intrnational Journal of Science and Technology (USTE) Vol.2 no 4.Desember 2013. 25-29.

Irwenda dkk, (2016). Sosis Ikan Kembung (Rastrelliger Kanagurta L.) sebagai Pangan Sumber Omega 3. Jurnal Aplikasi Teknologi Pangan Vol 5(3) 2016.

Martiana Ayu, 2015. Eksperimen Pembuatan Sosis ikan Lele Dumbo (Clarias gariepinus) Dengan Penambahan Wortel. Fak.Teknik UNES, Semarang. 
Nurlaila, et al (2016). Pengembangan Produk Sosis Fungsional Berbahan Dasar Ikan Tenggiri (Scomberomorus sp.) Dan Tepung Daun Kelor (Moringa oleifera) Jurnal Pendidikan Teknologi Pertanian, Vol. 2 (2016) : 105-113.

Restu, (2003). Pembuatan Otak-Otak Ikan Lele Dumbo (Clarian fuscus): Kajian dari Kelapa Parut dan Tapioka, Jurnal Central Kalimantan Fisheries. Vol.5. No. 1 Maret 2004 , (2003). Pembuatan Otak-Otak Ikan Lele Dumbo (Clarian fuscus):Pencetakan dan Lama Pengukusan, Jurnal Central Kalimantan Fisheries. Vol.5. No.1 Maret 2004

, (2011), Pembuatan Bakso Ikan Toman (Channa micropeltes). Jurnal Ilmu Hewani Tropika. Vol.I No.1 Juni 2012.

, (2012) Pemanfaatan Ikan Toman (Channa micropeltes) Sebagai Bahan Nuget. Jurnal Ilmu Hewani Tropika. Vol.I No.2 Desember 2012
Sastrosupadi, 1999. Rancangan Percobaan Praktis (Bid. Pertanian). Penerbit Kanisius, Jogyakarta.

Simon BW dkk, (2003). Studi Kualitas FisikKimia Sosis ikan lele dumbo (Clarias gariepinus) akibat pengaruh Perebusan, Pengukusan dan Kombinasinya dengan Pengasapan. Jurnal Teknologi Pertanian Unibraw Vol 4 No.3:193-202

Yulindra dkk, (2013). Pengaruh Konsentrasi Residu Daging Ekstraksi Albumin Ikan Gabus (Ophiocephalus striatus) Yang Berbeda Terhadap Kualitas Sosis Ikan. Jurnal Mahassiswa Teknologi Hasil Perikanan. Vol 1 (2) 2013.

Tjokroadikusumo, P.S., (1986). HFS dan Industri Ubi Kayu Lainnya. PT. Gramedia. Jakarta.

Verly Dotulong, (2009). Nilai Proksimat Sosis ikan Ekor Kuning (Caesio spp) Berdasarkan Jenis Casing dan Lama Penyimpanan. Pacific Journal Vol 1(4) Juli 2009: 506-509 